\title{
Possibilities for Change of Thermoplastic Tensile Properties Using Admixture of Recyclable Material
}

Ján Majerník, Ján Kmec, Monika Karková, Martin Podařil

Institute of Technology and Business in České Budějovice, Okružní 517/10, 370014 České Budějovice, Czech Republic, E-mail: majernik@mail.vstecb.cz

Polymeric materials are thanks its processing and utility properties materials in demand of common and special use. They are also largely replacing conventional materials. As the popularity of polymeric materials grows, also the amount of its waste increases. For this reason, there is introduced the term recycling as a method of processing, re-use of the waste, into technologies of polymeric processing. So, this paper deals with the possibilities of introduction of recycled material. The main part of this paper is created by an experiment that explores the changes of tensile properties of test specimen according to the selected percentage of additives in the volume of the basic granulate. The test specimen was produced by mixing pure granules with the addition of recycled and re-granulated materials. The conclusion of this work presents a comparison of the results of each tensile test that provide an overview of the behaviour and properties of the materials tested.

Keywords: thermoplastic, recycled material, tensile test

\section{References}

[1] STN EN ISO 294-1. Plasty. Vstrekovanie skúšobných telies z termoplastových materiálov. Čast' 1: Všeobecné princípy a vstrekovanie viacúčelových a tyčinkových skúšobných telies. Bratislava: Slovenský ústav technickej normalizácie, 2001. 20 p.

[2] STN EN ISO 527-1. Plasty. Stanovenie t’ahových vlastností. Čast' 1: Všeobecné zásady. Bratislava: Slovenský ústav technickej normalizácie, 2012.

[3] STN EN ISO 527-2. Plasty. Stanovenie t’ahových vlastností. Čast' 2: Skúšobné podmienky pre lisované a vytláčané plasty. Bratislava: Slovenský ústav technickej normalizácie, 2012.

[4] RAZ, K., ZAHALKA, M., CHVAL, Z. (2017). Injection Molding Quality Improvement by Advanced Virtual Simulations. MANUFACTURING TECHNOLOGY, 2017, vol. 17, no. 1, p. 79-83. ISSN 1213-2489.

[5] DVORAK, Z., HNATKOVA, E., SEDLACIK, M. (2016). Mold Surface Contamination during Polymer Processing. MANUFACTURING TECHNOLOGY, 2016, vol. 16, no. 1, p. 63-69. ISSN 1213-2489.

[6] NIGROVIČ, R., MEŠKO, J. (2016). Laser Cutting of Non-Metallic Material - PMMA. MANUFACTURING TECHNOLOGY, 2016, vol. 16, no. 2, p. 402-406. ISSN 1213-2489.

[7] RAGAN, E., RUŽBARSKÝ, J., MAŇAS, M., et al. (2008). Vstrekovanie a spracovanie plastických hmôt. 1 st ed. Prešov: Fakulta výrobných technológií si sídlom v Prešove, 2008. 548 p. ISBN 978-80-7300-250-3

[8] GREŠKOVIČ, F., DULEBOVÁ, L', VARGA, J. (2010). Technológie spracovania plastov: Vstrekovanie. 1st ed. Košice: Strojnícka fakulta TUKE, 2010. 200 p. ISBN 978-80-553-0369-7.

[9] VALÁŠEK, P., MÜLlER, M. (2012). Polymeric particle composites with filler saturated matrix. MANUFACTURING TECHNOLOGY, 2012, vol. 12, no. 13, p. 272-276. ISSN 1213-2489.

[10] VALÁŠEK, P., MÜLLER, M. (2013). Changes of Polyurethane Mechanical Properties Filled with Glass Powder. MANUFACTURING TECHNOLOGY, 2013, vol. 13, no. 4, p. 563-568. ISSN 1213-2489. 